\title{
Pengembangan E-Modul Berbantu Kodular pada Smarthphone untuk Meningkatkan Kemampuan Literasi Matematis Siswa SMP
}

\author{
Yossy Rizqiyani ${ }^{1}$, Nurul Anriani ${ }^{2}$, Aan Subhan Pamungkas ${ }^{3}$ \\ ${ }^{1,2,3}$ Program Studi Pendidikan Matematika, FKIP, Universitas Sultan Ageng Tirtayasa, \\ Jl. Ciwaru Raya, Cipare, Kec. Serang, Kota Serang, Banten 42117 \\ yossyrizqiyani10@gmail.com
}

\begin{abstract}
This research aims to produce a product in the form of codular assisted e-module on the smartphonethat is valid, practicaland effective in improving students' mathematical literacy skills. This research is a development research that refers to the ADDIE model with five development stages, namely Analyze, Design, development, implementation and evaluation. The subject of this research is the students'of VIII Gclass at SMP Negeri 1 Kota Serang. Based on the resultof data analysiss, it isfound that score for the material expert test is obtainde with a validity percentage of $73 \%$ as "Valid" category. Fore the validity test conducted on media expert is obtained the reseult in percentage of $76 \%$ as "Valid" category. Beside, for the practicality test conducted on mathematics teaxchers is obtained the percentage of result of $85 \%$ ad "Very Practical" category, and students' response to learning media obtained a percentage result of 79 as "Good" category.The effectiveness of mathematic literacy e-module based on the n-gain score is 0.61 with interpretation there is an increase in the medium category. Therefore, codular assisted e-module on smartphones to improve students' mathematic literacy skill can be concluded that it is valid, practical, and effective to be used as mathematic literacy learning media for junior high school.
\end{abstract}

Keywords: E-module, Mathematics Literacy Skills, Kodular

\begin{abstract}
Abstrak
Penelitian ini bertujuan untuk menghasilkan produk berupa e-modul bebantu kodular pada smartphone yang valid, praktis serta efekktif dalam meningkatkan kemampuan literasi matematis siswa. Penelitian ini merupakan penelitian pengembangan yang mengacu pada model ADDIE dengan lima tahap pengembangan, yaitu Analyze, Design, Develompment, Implementation. Subjek penelitian ini adalah siswa kelas VIIIG SMP Negeri 1 kota Serang. Berdasarkan hasil analisis data diperoleh nilai untuk uji ahli materi dengan persentase kevalidan sebesar 73\% dengan kategori "valid". Untuk uji validasi oleh ahli media diperoleh persentase sebesar $76 \%$ dengan kategori "valid". Serta untuk uji kepraktisan yang dilakukan kepada guru mata pelajaran matematika diperoleh hasil persentase sebesar $85 \%$ dengan kategori "sangat praktis". dan respon siswa terhadap media pembelajaran memperoleh hasil persentase sebesar 79\% dengan kategori "baik". Keefektifan e-modul literasi matematis berdasarkan skor $n$-gain sebesar 0.61 dengan interpretasi terdapat peningkatan pada kategori sedang. Oleh karena itu, e-modul berbantu kodular pada smartphone untuk meningkat kemampuan literasi matematis siswa dapat disimpulkan valid, praktis serta efektif digunakan sebagai media pembelajaran matematika di SMP Kelas VIII.
\end{abstract}

Kata Kunci: E-Modul, Kemampuan Literasi Matematis, Kodular

Copyright (c) 2022 Yossy Rizqiyani, Nurul Anriani, Aan Subhan Pamungkas

$\triangle$ Corresponding author: Yossy Rizqiyani

Email Address: yossyrizqiyani10@gmail.com (Cibeber, Cilegon, Banten)

Received 06 December 2021, Accepted 19 January 2022, Published 23 February 2022

\section{PENDAHULUAN}

Pendidikan memiliki peranan penting dalam memajukan peradaban bangsa. Bangsa yang besar memiliki kualitas pendidikan yang baik. Hal ini sejalan dengan Haryanto (2015), kualitas pendidikan mempengaruhi kualitas dari suatu peradaban bangsa. Bangsa yang dapat meraih kemajuan serta menguasai dunia adalah bangsa yang memahami makna strategis pendidikan. Pendidikan nasional Indonesia mengacu pada pengembangan, pemberdayaan, dan pembentukan kepribadian peserta didik. Sebagaimana tertera dalam Depdiknas (2003) mengenai pendidikan nasional yang berfungsi mengembangankan kemampuan serta membentuk watak yang baik, berahlak mulia, beriman dan 
bertakwa kepada Tuhan Yang Maha Esa, berilmu, cakap, sehat, kreatif, mandiri serta menjadi warga negara yang demokratis serta bertanggung jawab. Sejalan dengan makna strategis pendidikan dan tujuan pendidikan di Indonesia, pembelajaran matematika memiliki peranan penting dalam mengembangkan kemampuan dan pembentukan kepribadian siswa.

Pembelajaran matematika dapat melatih siswa berpikir kritis, logis dan rasional sehingga siswa mampu mengembangkan kemampuan dirinya menjadi kepribadian yang berkompeten dan berkualitas serta dapat mewujudkan tujuan pendidikan nasional. Selain itu, matematika bukan hanya berguna sebagai ilmu pengetahuan, matematika pula berguna untuk memecahkan masalah kehidupan seharihari. Hal ini sejalan dengan pernyataan Novitasari \& Wilujeng (2018) matematika yang diajarkan bukan hanya dapat memecahkan masalah matematika saja tetapi juga mengajarkan pola pikir siswa menjadi logis, kritis dan rasional sehingga siswa dapat bersaing dan memecahkan masalah kehidupan dengan tepat.

Siswa banyak yang menganggap matematika sulit untuk dipahami. Hal ini disebabkan siswa tidak terbiasa menyelesaikan permasalahan matematika dengan menerapkan standar proses pembelajaran matematika. Standar proses tersebut yang dapat mengarahkan siswa untuk mampu menyelesaikan permasalahan matematika. Standar proses pembelajaran matematika terdapat lima komponen yakni kemampuan pemecahan masalah, kemampuan koneksi, kemampuan komunikasi, kemampuan penalaran, dan kemampuan representative (NCTM, 2020). Kemampuan tersebut akan tercapai bilamana kemampuan literasi matematika siswa diterapkan dalam pembelajaran. Literasi matematis adalah pengetahuan untuk mengetahui dan menerapkan dasar matematika dalam kehidupan sehari-hari (Ojose, 2011). Kemampuan Literasi matematika pula diartikan sebagai kemampuan seseorang dalam merumuskan, menggunakan, dan menafsirkan matematika dalam berbagai konteks untuk menggambarkan, memprediksi, dan menjelaskan fenomena (OECD, 2020).

Studi yang dikembangkan oleh PISA 2018, Indonesia sendiri memiliki hasil bahwa, siswa di Indonesia pandai dalam mencari informasi, mengevaluasi, dan merefleksi informasi tetapi lemah dalam memahami informasi. Pada hasil PISA tahun 2015 peringkat Indonesia pada bidang matematika adalah 63 dari 69 negara yang mengikuti tes PISA tersebut (Pratiwi, 2019). Selain itu, hasil PISA 2018 menghasilkan bidang matematika masih dibawah standar rata-rata PISA (OECD, 2020). Dalam pengujian yang dilakukan oleh PISA, seluruh komponennya menunjukan bahwa Indonesia masih kurang baik dalam memecahkan masalah terkait dengan kemampuan literasi. Kemampuan memahami informasi, menalar, dan menginterpretasikan suatu konteks masalah cenderung masih belum memenuhi tingkat kelayakan PISA. Kemampuan literasi matematis siswa dengan kemampuan matematis tinggi, sedang dan rendah di tiga SMP menunjukan bahwa lebih banyak berada pada level 1 dan 2 pada soal PISA dengan persentase ketercapaian siswa 86,50\% dan 68,93\%. Sedangkan, untuk level kemampuan tinggi level 3, level 4, level 5, dan level 6 pada tiga kategori kemampuan matematika rata-rata masih tergolong kurang memuaskan. Terlihat dari hasil yaitu hanya sebesar $46,14 \%, 56,26 \%, 36,90 \%$, dan 23,37\%. Sehingga dapat disimpulkan dari 
penelitian tersebut, kemampuan siswa dalam menyelesaikaan soal matematika model PISA masih tergolong rendah. Hal ini disebabkan kurangnya kemampuan siswa dalam mengkomunikasikan masalah, membuat pemodelan, merepresentasikan permasalahan serta lemahnya kemampuan bernalar (Ahmad \& Fauzan, 2019).

Berdasarkan hasil penelitiaan dari Hilaliyah dkk, (2019) berdasarkan hasil uji tes kemampuan literasi kepada 39 dari 42 siswa kelas VII di SMP Negeri 5 Kota Serang, sebanyak 3 orang siswa mampu mencapai level 2, 5 orang siswa mampu mencapai level 3, 10 orang siswa mampu mencapai level 4, 16 orang mencapai level 5, dan 8 orang mencapai level 6. Rata-rata nilai kelas memperoleh skor 602,33 dan berada pada level 4. Selain itu, dari hasil penelitian analisis Amelia dkk, (2020) mengenai identifikasi penyelesaian soal literasi matematika siswa kelas IX SMP 8 Kota Serang sebanyak 5 siswa dapat menjawab dengan benar dari 23 siswa terpilih. Maka terlihat bahwa kurang dari $79 \%$ yang dapat menyelesaikan soal literasi matematika dengan baik atau tidak ada setengah dari jumlah siswa yang mengikuti tes mampu menjawab soal dengan benar. Dari hasil kedua penelitian di atas, menunjukan bahwa wilayah SMP Kota serang masih cukup rendah kemampuan literasi matematis. Sehingga diperlukan media pembelajaran yang dapat mengasah dan melatih kemampuan literasi matematis siswa di Kota Serang agar semakin baik.

Pada proses ketercapaian siswa dalam meningkatkan kemampuan literasi matematis, diperlukan media pembelajaran yang tepat agar siswa dapat memahami pembelajaran.Media pembelajaran yang dipergunakan harus sesuai dengan tuntutan perkembangan zaman. Menurut Solihudin JH, (2018) dari hasil observasi kepada siswa, menunjukan media pembelajaran yang dibutuhkan oleh siswa yakni media pembelajaran yang mudah digunakan, mudah diakses serta dapat mempermudah siswa memahami pembelajaran. Media pembelajaran yang mudah dipergunakan dalam proses pembelajaran matematika salah satunya adalah modul elektronik. Modul elektronik merupakan seperangkat media pembelajaran digital dan non cetak yang disusun secara sistematis dapat dipergunakan secara mandiri oleh siswa, sehingga menuntut siswa mampu memecahkan permasalahan dengan caranya sendiri (Kemendikbud, 2017). Pada tahun 2017 hasil survey TIK oleh Kominfo, (2017) menunjukan 66,3\% individu memiliki smartphone. Berdasarkan pendidikan yang ditempuh, 59,89\% sekolah menengah pertama (SMP) sudah menggunakan smartphone. Penggunaan smartphone menjadikan siswa lebih mudah belajar secara mandiri, kreatif dan inovatif (Alhady et al., 2018). Memiliki fitur yang menunjang proses belajar serta dapat di akses kapan saja membuat smartphone memberikan kemudahan bagi mahasiswa dalam melakukan pembelajaran (J.Haq, 2017).

Berdasarkan penelitian yang dilakukan oleh Yuniarti dkk., (2020) menunjukan bahwa pengembangan media pembelajaran e-modul interaktif berbasis smartphone Pada Materi Integral Tak Tentu Berorientasi Keterampilan Abad Ke-21 mendapatkan hasil keefektivitasan sebesar 70\% atau berkategori tinggi. Hal ini sejalan dengan penelitian Pamungkas, (2020) mengungkapkan bahwa penggunaan e-modul berbantu kodular hasil uji kelayakan menggunakan SUS diperoleh nilai sebesar 71 atau dikategorikan dapat diterima dikelas pembelajaran dan masuk ke dalam peringkat naik. Selain 
itu, peneliti tersebut mengungkapkan pembelajaran menggunakan media pembelajaran kodular lebih efektif dibandingkan dengan tanpa menggunakan media pembelajaran kodular. Dari paparan yang dijelaskan di atas, maka peneliti bermaksud melakukan penelitian pengembangan e-modul berbantu kodular untuk memudahkan siswa mempelajari materi teorema pythagoras serta meningkatkan kemampuan literasi matematis siswa. Dari paparan yang dijelaskan di atas, tujuan yang dicapai pada penelitian ini adalah mengembangkan "E-Modul Berbantu Kodular Untuk Meningkatkan Kemampuan Literasi Matematis Siswa SMP”.

\section{METODE}

Metode yang digunakan dalam penelitian pengembangan ini adalah metode penelitian research development (R\&D). Prosedur pengembangan yang dilakukan menggunakan model ADDIE yang diadaptasi oleh teori (Lee \& Owens, 2004). Pengujian produk tersebut akan dilakukan dengan pengujian oleh ahli dan penguji cobaan produk. Kemudian untuk pengembangan yang akan dilakukan peneliti adalah pengembangan media pembelajaran berupa e-modul berbantu kodular menggunakan smartphone untuk meningkatkan kemampuan literasi matematis siswa kelas VIII SMP yang dilaksanakan pada SMP Negeri 1 Kota Serang. Subjek penelitian adalah siswa kelas VIIIG. Kelas tersebut dipilih secara acak oleh guru mata pelajaran matematika di SMP tersebut. Prosedur yang digunakan dalam pengembangan produk e-modul berbantu kodular ini menggunakan prosedur pengembangan model ADDIE yang diadaptasi dari teori (Lee \& Owens, 2004). Alur pengembangan ADDIE merupakaan sebuah siklus, yang dibatasi oleh satu siklus. Secara lengkap prosedur pengembangan produk pada penelitian ini dapat di deskripsikan pada diagram alir berikut:

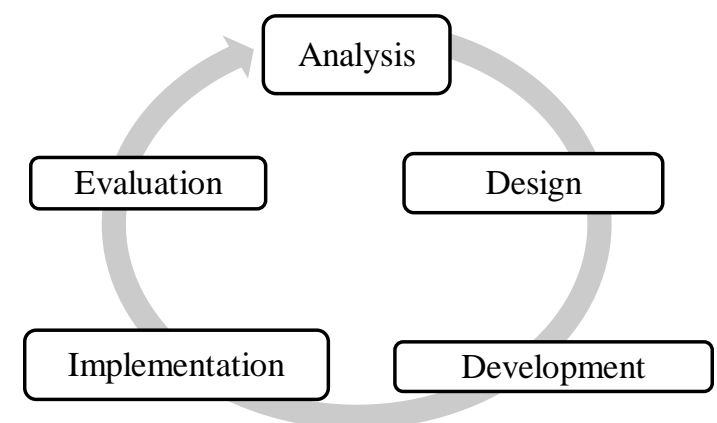

Gambar 1. Prosedur Pengembangan ADDIE

Instrumen penelitian merupakan alat yang berfungsi untuk mengumpulkan data penelitian dengan cara melakukan pengukuran (Widoyoko, 2012). Terdapat dua jenis instrumen pengumpulan data yaitu, instrumen tes dan non tes. Instrumen dalam penelitian pengembangan ini digunakan untuk mengetahui kelayakan produk dan mengevaluasi e-modul dapat meningkatkan kemampuan literasi matematis siswa. Instrumenpenelitian terdiri dari instrumen kevalidan, kepraktisan, serta keefektivitasan dari media pembelajaran yang dikembangkan. Instrumen validasi ahli media yang digunakan dalam penelitian ini berupa angket. Angket dibuat untuk mengetahui kualitas media 
pembelajaran dari segi multimedia pembelajaran. Instrumen ini berisi aspek tampilan visual, kemudahan penggunaan, konsistensi, kemanfaatan dan aspek kegrafikan. Instrumen validasi ahli materi yang digunakan dalam penelitian ini untuk ahli materi yang berisi aspek kelayakan isi, kelayakan kebahasaan, serta aspek kelayakan penyajian.

Angket respon siswa digunakan untuk memperoleh data mengenai respon siswa terhadap pengembangan media pembelajaran. Angket ini disusun berdasarkan tiga aspek yaitu: aspek kualitas isi, aspek kualitas penggunaan dan aspek instruksional. Angket respon guru digunakan untuk memperoleh data mengenai respon guru terhadap pengembangan media pembelajaran. Angket ini disusun berdasarkan tiga aspek yaitu: aspek kelayakan isi, kelayakan kebahasaan, aspek kelayakan penyajian, serta aspek kemudahan penggunaan. Instrumen kemampuan literasi matematis. Instrumen ini berupa soal pretest dan postest literasi matematis terdiri dari soal uraian sebanyak 3 butir soal pretest dan posttest dengan mengandung komponen literasi matematis pada setiap soal. Instrumen ini berfungsi untuk mengetahui perubahan peningkatan pemahaman siswa pada kemampuan literasi matematis setelah mengikuti pembelajaran menggunakan media pembelajaran yang dikembangkan.

Teknis analisis data dalam penelitian ini yaitu memaparkan hasil pengembangan berupa modul elektronik matematika berbantu kodular pada materi teorema Pythagoras. Analisis data dilakukan setelah data terkumpul berdasarkan hasil angket validasi ahli media, ahli materi serta respon siswa yang menggunakan skala 1 sampai 4 . Tertera pada tabel 1.

Tabel 1. Skor Penilaian Validasi

\begin{tabular}{|l|c|}
\hline \multicolumn{1}{|c|}{ Keterangan } & Skor \\
\hline STS = Sangat Tidak Setuju & 1 \\
\hline TS = Tidak Setuju & 2 \\
\hline S = Setuju & 3 \\
\hline SS = Sangat Setuju & 4 \\
\hline
\end{tabular}

Selanjutnya data dianalisa menggunakan rumus dan kategori yang diadaptasi oleh (Arikunto dan Jabar, 2010). Serta analisis data kemampuan literasi matematis menggunakan pedoman penskoran dan analisis data $n$-gain.

$$
P=\frac{f}{N} \times 100 \%
$$

Keterangan :

$\mathrm{P}=$ Persentase Jawaban $(\%)$

$\mathrm{f}=$ Frekuensi Jawaban

$\mathrm{N}$ = Banyaknya Responden

Setelah data diolah menjadi persentase kemudian uji validitas ahli media dan ahli materi dilihat dari kategori validitas pada tabel 2 . 
Tabel 2. Kategori Validitas

\begin{tabular}{|c|c|}
\hline Persentase Skor (\%) & Kategori Validitas \\
\hline $\mathrm{P} \leq 21$ & Sangat tidak valid \\
\hline $21<P \leq 40$ & Tidak valid \\
\hline $41<P \leq 60$ & Cukup valid \\
\hline $61<P \leq 80$ & Valid \\
\hline $81<P \leq 100$ & Sangat valid \\
\hline
\end{tabular}

Persentase selanjutnya adalah respon siswa, persentase respon siswa akan dikategorikan berdasarkan kategori sesuai dengan tabel 3.

Tabel 3. Kategori Respon Siswa

\begin{tabular}{|c|c|}
\hline Persentase Skor (\%) & Kategori Validitas \\
\hline $\mathrm{P} \leq 21$ & Sangat buruk \\
\hline $21<P \leq 40$ & Buruk \\
\hline $41<P \leq 60$ & Cukup \\
\hline $61<P \leq 80$ & Baik \\
\hline $81<P \leq 100$ & Sangat baik \\
\hline
\end{tabular}

Tes kemampuan literasi matematis akan dianalisis dengan mengadopsi teori Hake, (1998) yaitu gain ternormalisasi (n-gain). Kemudian data hasil tes kemampuan literasi matematis baik pretest dan posttest akan dihitung dengan menggunakan normalized gain untuk melihat apakah e-modul yang dibuat mampu meningkatkan kemampuan literasi matematis siswa. Perhitungan n-gain dilakukan untuk memberikan gambaran umum peningkatan skor hasil pembelajaran antara pretest dan posttest penerapan media pembelajaran.

$$
g=\frac{S_{f}-S_{i}}{S_{M a x}-S_{i}}
$$

Keterangan :

$\mathrm{g}=$ Gain ternormalisasi

$S_{f}=$ Skor Posttest

$S_{i}=$ Skor Pretest

$S_{\max }=$ Skor Maximum

Setelah dilakukan hasil perhitungan, maka untuk melihat kategori yang akan diperoleh diberikan kategorinya pada tabel 4.

Tabel 4. Interpretasi Skor n-gain

\begin{tabular}{|c|c|}
\hline Persentase Skor & Kategori Validitas \\
\hline$-1,00<\mathrm{g}<0.00$ & Menurun \\
\hline $\mathrm{g}=0.00$ & Stabil \\
\hline $0.00<\mathrm{g}<0.30$ & Rendah \\
\hline $0.30<\mathrm{g}<0.70$ & Sedang \\
\hline $0.70<\mathrm{g}<1.00$ & Tinggi \\
\hline
\end{tabular}




\section{HASIL DAN DISKUSI}

Penelitian ini mengahasilkan produk berupa aplikasi modul pembelajaran berbantu kodular pada smartphone untuk meningkatkan kemampuan literasi matematis siswa SMP kelas VIII. E-modul ini digunakan sebagai salah satu sumber belajar yang dapat diakses kapan saja. Secara rinci penelitian pengembangan yang telah dilakukan sebagai berikut.

\section{Analysis}

Analisis kebutuhan dilakukan untuk mengetahui kebutuhan mengenai kemampuan matematis siswa dan proses pembelajaran dengan bahan ajar yang digunakan. Pada tahap ini peneliti melakukan wawancara kepada guru matematika di SMPN 1 Kota Serang diperoleh informasi bahwa kemampuan literasi matematis siswa cenderung mampu menyelsaikan maslah tetapi belum dengan penggunaan standar proses penyelesaian matematika. Dalam proses pembelajaran guru membutuhkan sumber belajar untuk siswa yang dapat menjadi fasilitas maupun pengukuran kemapuan siswanya dalam satu wadah pembelajaran. Analisis karakteristik siswa dilakukan untuk mengetahui siswa dalam penggunaan teknologi sudah dapat menguasai atau belum. Berdasarkan wawancara kepada guru SMPN 1 kota Serang diperoleh informasi bahwa sebagian besar siswa sudah dapat menggunakan teknoogi serta sekitar $80 \%$ siswa sudah memiliki ataupun menggunakan smartphone. Analisis kurikulum dilakukan untuk menyesuaikan dengan e-modul yang akan dibuat. Kurikulum yang digunakan oleh guru dalam kegiatan belajar mengajar di SMPN 1 Kota Serang adalah kurikulum 2013 revisi 2017. Sehingga seluruh komponenn modul disesuaikan dnegan kurikulum tersbeut. Analisis media dilakukan untuk mengetahui media pembelajaran apa saja yang dipergunakan oleh SMPN 1 kota Serang. Berdasarkan hasil analisis kebutuhan, karakteristik siswa, kurikulum serta media maka media pembelajaran yang perlu dikembangkan adalah media berbentuk modul elektronik yang memuat kemampuan literasi matematis yang luaran berbentuk aplikasi sehingga e-modul tersebut dapat diakses kapan saja dan di mana saja.

\section{Design}

Perancangan modul pembelajaran berbantu kodular dilakukan sesuai dengan tahap analisis yang telah dilakukan. Meliputi analisis kebutuhan, analisis karakteristik siswa, analisis media dan analisis kurikulum. Aplikasi ini dibuat dengan komponen materi, latihan soal, quiz serta forum diskusi antar guru dengan siswa. Perancangan e-modul dilakukan dengan menggunakan flowchart. Flowchart merupakan gambaran dari suatu langkah-langkah dan urutan dari prosedur suatu program. Flowchart penting dilakukan agar mempermudah pengembangan media pembelajaran. Selain itu, dijabarkan lebih rinci menggunakan storyboard.

\section{Develompment}

Tahapan pengembangan yang dilakukan merupakan tahapan perwujudan dari storyboard yang telah dirancang pada tahapan design. Produk yang dihasilkan adalah e-modul berbentuk aplikasi android berbentuk file Apk sehingga hanya tinggal diunduh saja. pengembangan e-modul dilakukan dengan berbantu kodular. Tahapan pembuatannya mendesain dengan menggunakan koding yang di 
Pengembangan E-Modul Berbantu Kodular pada Smarthphone untuk Meningkatkan Kemampuan Literasi Matematis Siswa SMP, Yossy Rizqiyani, Nurul Anriani, Aan Subhan Pamungkas

drag and drop saja. Tahapan ini terdiri dari tiga tahap pelaksanaan, diantaranya:

1. Pembuatan aplikasi

Nama media pembelajaran

Materi

Isi Media

Fitur unggulan

Media Penyebar Luasan
: Modul Literasi Matematis

: Teorema Pythagoras

: Home, Pendahuluan, KI dan KD, Materi,

Latihan, Evaluasi, Informasi, serta Contact.

: Personal Chat, Game dan Evaluasi

: dapat diunduh melalui

https://drive.google.com/file/d/1ebTYdNO2Uuw72BmJDBx

4QUm6HbbRDMGY/view?usp=sharing

Berikut ini fitur-fitur yang ada dalam e-modul literasi matematis.

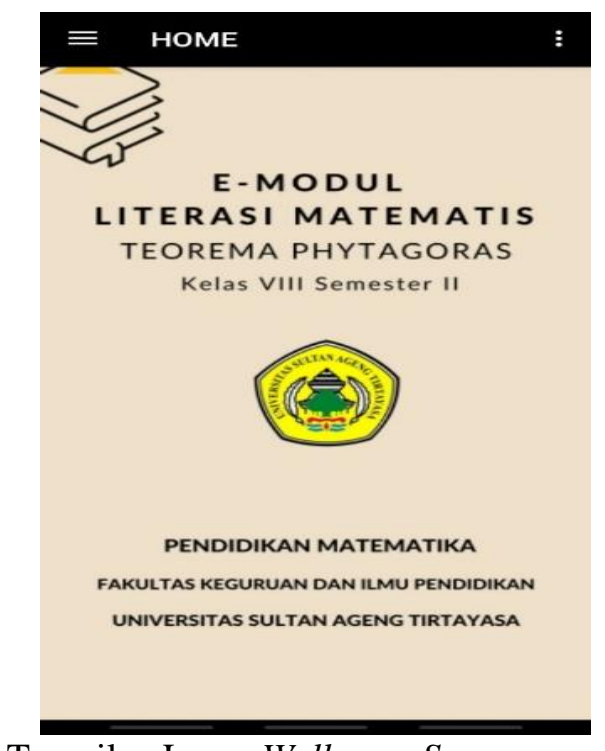

Tampilan Layar Wellcome Screen

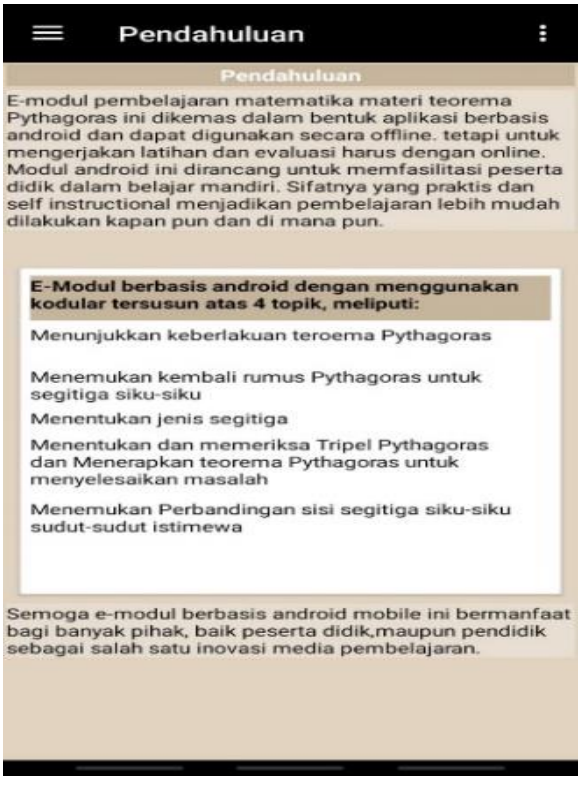

Tampilan Menu Pendahuluan

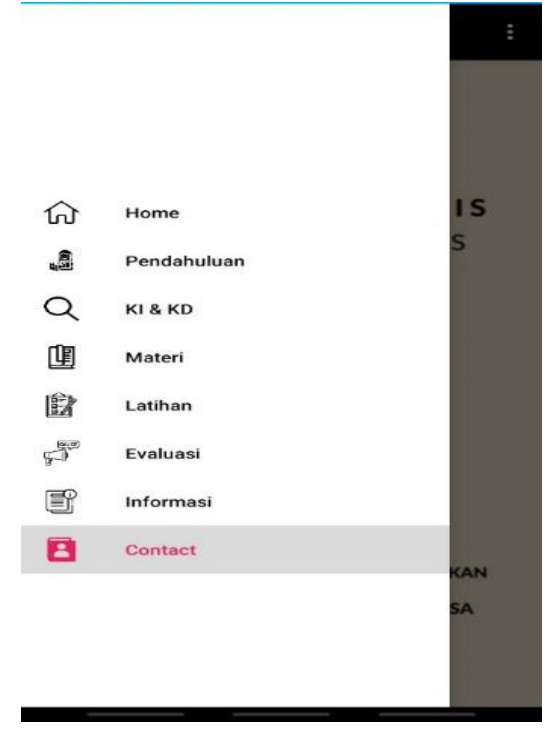

Tampilan Menu Home
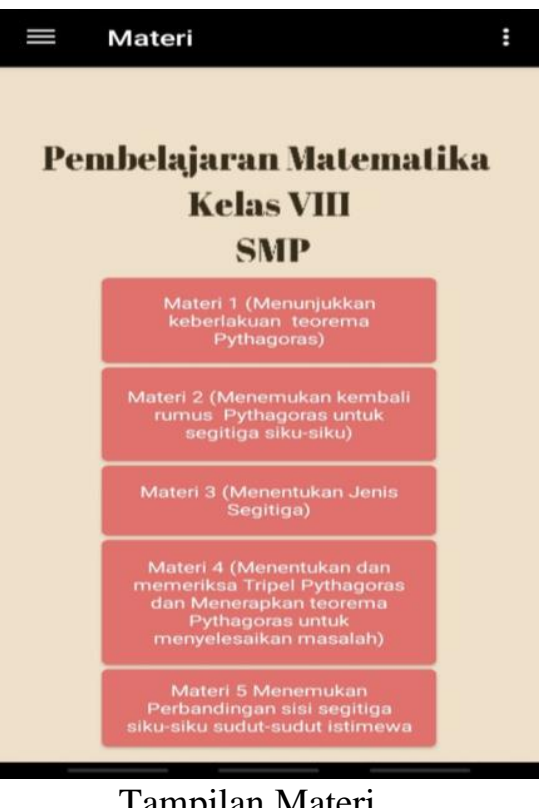

Tampilan Materi 


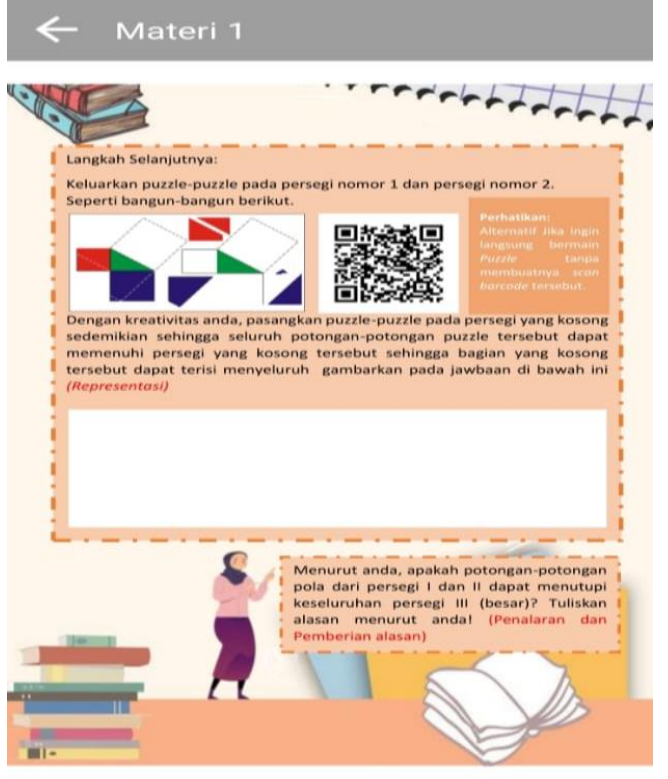

Tampilan Menu Materi

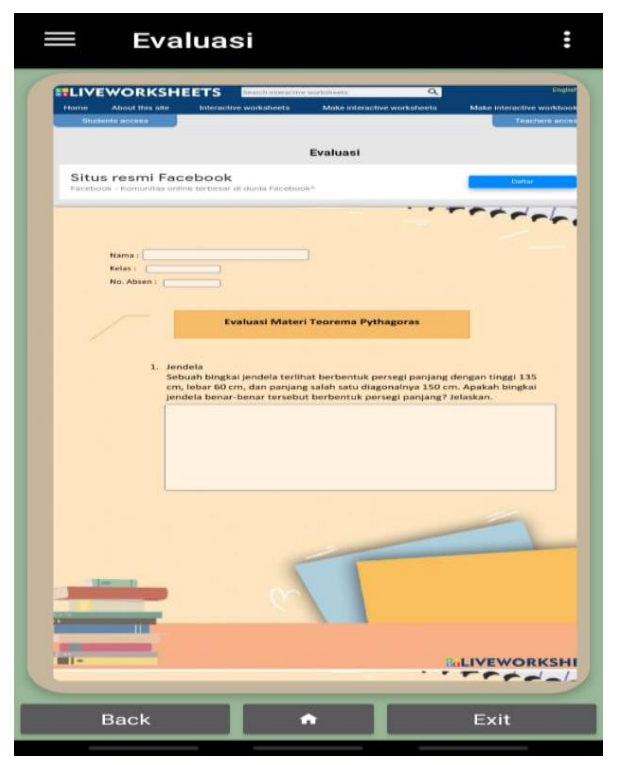

Tampilan Menu Evaluasi

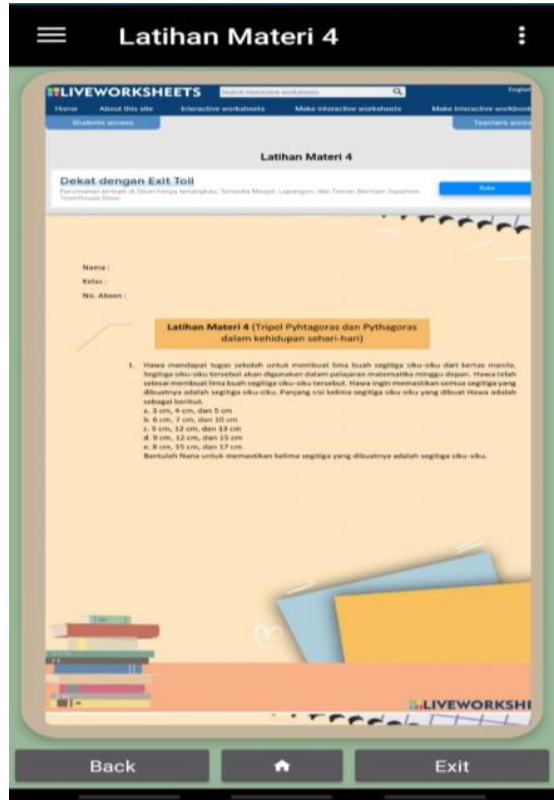

Tampilan Menu Latihan

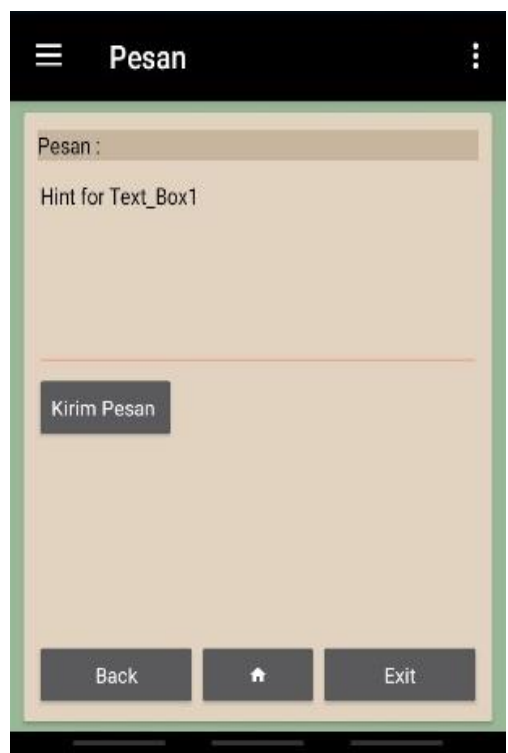

Tampilan Menu Kontak

Gambar 2. Bagian E-Modul

\section{Uji ahli}

Hasil dari pengembangan yang telah dilakukan kemudian dilanjutkan dengan uji ahli oleh para ahli untuk mengetahui tingkat kelayakan e-modul dan selanjutnya saran yang diperoleh akan menjadi perbaikan untuk e-modul pembelajaran ini. uji ahli dilakukan kepada ahli media pembelajaran dan ahli materi.

Ahli media pembelajaran dilakukan untuk melihat apakah media tersebut layak dari segi tampilan visual layar, kemudahan penggunaan, konsistensi, kemanfaatan, serta kegrafikan. Media pembelajaran dilakukan kepada seorang dosen ahli media. Hasil penilaian media pembelajaran dapat dilihat pada 
tabel 5.

Tabel 5. Hasil Uji Ahli Media Pembelajaran

\begin{tabular}{|l|l|c|c|c|}
\hline No. & \multicolumn{1}{|c|}{ Aspek } & Jumlah Skor & Skor Maksimal & Persentase \\
\hline 1. & Tampilan Visual Layar & 21 & 28 & $75 \%$ \\
\hline 2. & Kemudahan Penggunaan & 8 & 12 & $67 \%$ \\
\hline 3. & Konsistensi & 10 & 12 & $83 \%$ \\
\hline 4. & Kemanfaatan & 19 & 24 & $79 \%$ \\
\hline 5. & Kegrafikan & 9 & 12 & $75 \%$ \\
\hline \multicolumn{2}{|l}{ Total Keseluruhan } & $\mathbf{6 7}$ & $\mathbf{8 8}$ & $\mathbf{7 6 \%}$ \\
\hline
\end{tabular}

Keseluruhan aspek media memiliki rata-rata penialain sebesar $76 \%$ dengan kategori valid. Sehingga e-modul literasi matematis dapat digunakan dalam pelaksanaan pembelajaran disekolah. Penilaian yang dilakukan oleh penguji ahli media terdapat saran yang dapat menjadi perbaikan bagi media pembelajaran e-modul literasi matematis Masukan tersebut adalah memasukan menu back (kembali) pada setiap halaman menu, sehingga tidak perlu kembali ke menu Home. Kemudian peneliti melakukan penambahan tombol menu back pada setiap komponen tampilan layar.

Ahli materi melakukan uji ahli materi untuk melihat apakah e-modul tersebut layak dari segi isi, kelayakan kebahasaan, serta penyajian materi. Pengujian dilakukan kepada seorang dosen ahli materi. Hasil penilaian materi dari e-modul literasi matematis dapat dilihat pada tabel 6.

Tabel 6. Hasil Uji Ahli Materi

\begin{tabular}{|c|l|c|c|c|}
\hline No. & \multicolumn{1}{|c|}{ Aspek } & Jumlah Skor & Skor Maksimal & Persentase \\
\hline 1. & Kualitas Isi & 33 & 44 & $75 \%$ \\
\hline 2. & Kelayakan Kebahasaan & 15 & 20 & $75 \%$ \\
\hline 3. & Penyajian Materi & 14 & 20 & $70 \%$ \\
\hline \multicolumn{2}{|c|}{ Total Keseluruhan } & $\mathbf{6 2}$ & $\mathbf{8 4}$ & $\mathbf{7 3 , 3 \%}$ \\
\hline
\end{tabular}

Keseluruhan aspek materi memiliki rata-rata penilaian sebesar $73 \%$ dengan kategori valid. Sehingga e-modul literasi matematis sudah sesuai dan dapat digunakan dalam pelaksanaan pembelajaran disekolah. Pengujian yang dilakukan diperoleh saran yang dapat memperbaiki kualitas dari media pembelajaran. Pada uji ahli materi terdapat saran yang dapat menjadi perbaikan bagi emodul literasi matematis. Masukan tersebut yaitu menambahkan contoh soal aplikasi dan soal high order thinking skills (HOTS). Kemudian pengembang sudah menambahkan beberapa contoh soal dan latihan soal HOTS pada setiap materi.

\section{Implementation}

Pada tahap implementasi dilakukan pengujian kepada siswa dengan menggunakan media pembelajaran E-Modul literasi matematis dengan mengukur kemampuan literasi matematis siswa sebelum dan sesudah menggunakan media pembelajaran tersebut. Setelah itu diberikan angket untuk mengetahui respon penilaian siswa dan guru terhadap aplikasi E-Modul literasi matematis yang telah dikembangkan. Penilaian media pembelajaran oleh siswa diambil dari siswa kelas VIIIG SMP Negeri 1 Kota Serang, pengambilan data dilakukan sebanyak 15 orang siswa. Pelaksanaan uji coba E-Modul literasi matematis dilakukan dengan peneliti mengajarkan secara langsung kepada siswa secara daring. 
Sebelum pembelajaran siswa melakukan tes awal sebanyak tiga soal. Selanjutnya, siswa dibimbing dalam mempelajari materi teorema Pythagoras menggunakan e-modul literasi matematis. Setelah pembelajaran daring dengan menggunakan e-modul telah selesai, siswa diberikan tes akhir sebanyak tiga soal tes dengan komponen literasi matematis. Berikut ini pelaksanaan proses belajar mengajar dengan siswa.

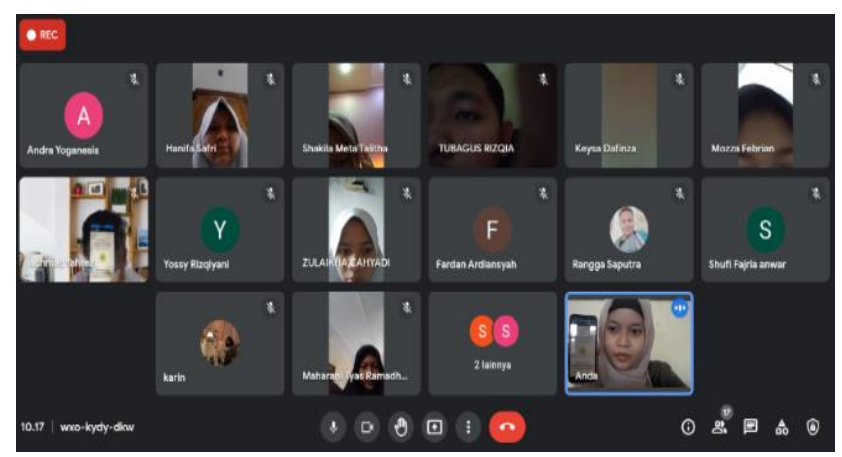

Gambar 2. Bagian E-Modul

Berikut merupakan hasil perhitungan nilai pretest dan posttest literasi matematis siswa, jika dihitung dengan menggunakan nilai $n$-gain. Jika dilihat dari segi masing-masing aspek kemampuan literasi matematis, dengan menggunakan nilai $n$-gain. Berikut merupakan nilai $n$-gain dari pretest dan posttest terlihat pada tabel 7 .

Tabel 7. Hasil Tes Kemampuan Literasi Matematis Berdasarkan Aspek

\begin{tabular}{|l|l|c|c|c|}
\hline No. & \multicolumn{1}{|c|}{ Aspek } & Tes Awal & Tes Akhir & $\begin{array}{c}\text { Normalized } \\
\text { Gain }\end{array}$ \\
\hline 1. & Penalaran & 46 & 142 & 0.30 \\
\hline 2. & Representasi & 62 & 78 & 0.13 \\
\hline 3. & Merencanakan Strategi & 0 & 32 & 0.18 \\
\hline 4. & Koneksi Matematis & 28 & 76 & 0.31 \\
\hline \multicolumn{2}{|l}{ Total Keseluruhan } & $\mathbf{1 3 6}$ & $\mathbf{3 2 8}$ & $\mathbf{0 . 2 5}$ \\
\hline
\end{tabular}

Dari tabel yang diperoleh di atas, aspek penalaran diperoleh $n$-gain sebesar 0.3 dengan interpretasi "sedang", aspek representasi diperoleh n-gain sebesar 0.13 dengan interpretasi nilai "rendah", aspek merencanakan strategi diperoleh $n$-gain sebesar 0.18 dengan interpretasi "rendah" serta untuk koneksi matematis diperoleh n-gain 0.31 dengan interpretasi "sedang". Dan untuk aspek keseluruhan diperoleh $n$-gain sebesar 0.25 dengan interpretasi "rendah".

Selanjutnya, setelah melakukan tes akhir siswa melakukan pengisian angket respon siswa. Pengisian angket tersebut dilakukan dengan menggunakan google form kepada siswa yang telah menggunakan e-modul literasi matematis dengan pendampingan untuk mendapatkan data kepraktisan media dan respon penggunaan e-modul literasi matematis berbantu kodular. Berikut merupakan hasil perhitungan respon siswa terhadap media pembelajaran e-modul literasi matematis. 
Tabel 8. Hasil Respon Siswa

\begin{tabular}{|l|l|c|c|c|}
\hline No. & \multicolumn{1}{|c|}{ Aspek } & Jumlah Skor & Skor Maksimal & Persentase \\
\hline 1. & Penyajian Materi & 385 & 480 & $80 \%$ \\
\hline 2. & Kebahasaan & 242 & 300 & $81 \%$ \\
\hline 3. & Kemanfaatan & 230 & 300 & $77 \%$ \\
\hline 4. & Kegrafikan & 141 & 180 & $78 \%$ \\
\hline \multicolumn{2}{|l|}{ Total Keseluruhan } & $\mathbf{9 9 8}$ & $\mathbf{1 2 6 0}$ & $\mathbf{7 9 , 2 \%}$ \\
\hline
\end{tabular}

Hasil respon siswa terhadap e-modul literasi terbagi kedalam empat aspek, yaitu aspek penyajian materi mendapatkan penilaian sebesar 80\% dengan kategori Baik, aspek kebahasaan mendapatkan penialaian sebesar $81 \%$ dengan kategori sangat baik, aspek kemanfaatan mendapatkan penilaian sebesar 77\% dengan kategori baik, serta aspek kegrafikan mendapatkan penilaian sebesar 78\% dengan kategori baik. Untuk keseluruhan aspek dari respon siswa memperoleh rata-rata penilaian sebesar $79,2 \%$ dengan kategori baik. Dalam pengambilan data respon siswa, peneliti meminta pendapat serta saran siswa mengenai e-modul literasi matematis. Menurut salah seorang siswa gambar yang ada pada modul terlihat samar atau kurang jelas. Setelah pembelajaran selesai dilakukan, peneliti juga meminta tanggapan guru mata pelajaran matematika untuk memberikan respon terhadap e-modul literasi matematis yang dikembangkan dengan memberikan angket kepraktisan guru yang pengisiannya dilakukan menggunakan google form dan dikirimkan melalui whatsapp. Berikut merupakan hasil dari angket kepraktisan guru.

Tabel 9. Hasil Uji Kepraktisan Guru

\begin{tabular}{|c|c|c|c|c|}
\hline No. & Aspek & Jumlah Skor & Skor Maksimal & Persentase \\
\hline 1. & Kualitas Isi & 37 & 44 & $84 \%$ \\
\hline 2. & Kelayakan Kebahasaan & 18 & 20 & $90 \%$ \\
\hline 3. & Penyajian Materi & 18 & 20 & $90 \%$ \\
\hline 4. & Kemudahan Penggunaan & 9 & 12 & $75 \%$ \\
\hline \multicolumn{2}{|c|}{ Total Keseluruhan } & $\mathbf{8 2}$ & $\mathbf{9 6}$ & $\mathbf{8 5 \%}$ \\
\hline
\end{tabular}

Terdapat empat aspek dalam angket kepraktisan guru. Aspek kualitas isi, aspek kelayakan kebahasaan, aspek penyajian materi, serta aspek kegrafikan. Pada keseluruhan aspek dari angket kepraktisan siswa memperoleh rata-rata penilaian sebesar 85\% dengan kategori sangat praktis. Sehingga dari hasil angket tersebut, e-modul literasi matematis dapat digunakan dalam kegiatan pembelajaran matematika disekolah.

\section{Evaluation}

Pada tahap evaluasi merupakan tahap akhir dari seluruh rangkaian pengembangan ADDIE. Setelah melakukan penilaian ahli media, ahli materi, pengambilan respon siswa serta pengujian kepraktisan yang dilakukan kepada guru diperoleh penilaian untuk uji validasi oleh ahli media dengan hasil "valid", dan uji validasi oleh ahli materi dengan hasil "valid". Serta untuk uji kepraktisan yang dilakukan kepada guru mata pelajaran matematika diperoleh hasil "sangat praktis" dan respon siswa terhadap media pembelajaran memperoleh hasil "baik". Setalah tahap implementasi sudah 
dilaksanakan, maka selanjutnya adalah melakukan revisi akhir terhadap media pembelajaran e-modul literasi matematis berdasarkan saran dan masukan oleh guru serta siswa selama uji coba produk sehingga e-modul literasi matematis dapat layak untuk digunakan dalam kegiatan pembelajaran.

Kepraktisan dari e-modul dilakukan dengan mengambil data hasil angket respon guru. Terlihat dari hasil angket respon yang menunjuan bahwa E-modul literasi matematis mudah digunakan. keseluruhan aspek dalam respon guru, diperoleh persentase sebesar 85\% dengan kategori sangat praktis. Dari hasil persentase kepraktisan oleh guru dan siswa, maka e-modul sudah layak sesuai yang dikatakan oleh (Prastowo, 2011; Rahdiyanta, 2009; Ramadanti dkk., 2021; Wahyuli, 2017) yaitu : a. modul dapat digunakan secara mandiri sesuai dengan kemampuan yang dimiliki siswa, b. modul dikemas secara lengkapdan praktis mengandung semua komponen kemampuan dasar, c. modul yang dibuat sesuai perkembangan zaman, serta d. modul yang disusun dengan menggunakan bahsa yang mmepermudah siswa memahami materi.

Berdasarkan hasil angket respon siswa dan guru pada e-modul literasi matematis yang telah dikembangkan menunjukan bahwa e-modul tersebut dapat digunakan, bermanfaat serta mudah digunakan untuk kegiatan pembelajaran matematika siswa terutama pada materi teorema Pythagoras. Oleh karena itu, e-modul literasi matematis yang dikembangkan dapat memenuhi kriteria praktis. Hal ini selaras dengan bebrapa penelitian sebelumnya, mengungkapkan pengembangan media pembelajaran efektif digunakan dalam pembelajaran (Cecep dkk., 2019; Pamungkas, 2020; Putri dkk., 2020).

Pada penelitian dengan menggunakan model ADDIE, tahap akhir yaitu tahap evaluasi. E-modul yang dikembangkan ini memperoleh hasil pengujian oleh ahli media dan materi dengan kategori valid. Selanjutnya, untuk respon guru mendapatkan hasil praktis sehingga dapat digunakan dalam kegiatan pembelajaran. Untuk hasil respon siswa diperoleh respon yang baik dan menyukai e-modul pembelajaran ini dilihat dari komentar atas angket respon siswa. Dan e-modul ini dilihat dari hasil tes dapat meningkatkan kemampuan literasi matematis siswa.

\section{KESIMPULAN}

Penelitian pengembangan ini telah menghasilkan produk e-modul berbantu kodular pada smrtphone dengan menggunakan model pengembangan model ADDIE yang valid, praktis, efektif untuk mengingkatkan kemapuan literasi matematis siswa. Hasil dari uji validitas ahli media dan ahli materi yaitu diperoleh hasil valid. E-modul yang dikembangkan juga memenuhi kriteria praktis dengan kategori penilaian kepraaktisan guru sangat praktis. Dan memenuhi pula kriteria efektif dari hasil pengujian kemmapuan literasi matematis siswa dengan peningkatan kategori sedang. Dari hasil yang dieroleh, maka e-modul literasi materi teorema Pythagoras layak untuk digunakaan dalam pembelajaran baik disekolah maupun dirumah. 
Pengembangan E-Modul Berbantu Kodular pada Smarthphone untuk Meningkatkan Kemampuan Literasi Matematis Siswa SMP, Yossy Rizqiyani, Nurul Anriani, Aan Subhan Pamungkas

\section{UCAPAN TERIMA KASIH}

Terima kasih kepada bapak Kepala Sekolah, Ibu Guru Matematika, serta seluruh siswa kelas VIII G di SMPN 1 Kota Serang atas kesempatan dan dukungan untuk melakukan penelitian.

\section{REFERENSI}

A Lee, W. W. \& Owens, D. L. (2004). Multimedia-based Instructional Design (Second edi). Pfeiffer.

Ahmad, R., \& Fauzan, A. (2019). Analisis Kemampuan Siswa dalam Menyelesaikan Soal Matematika Model Pisa pada Siswa Kelas IX SMP di Kota Padang. Jurnal Edukasi Dan Penelitian ..., 8(3), 110-117. http://repository.unp.ac.id/id/eprint/22425

Alhady, N. C., Salsabila, A. F., \& Azizah, N. N. (2018). Penggunaan Smartphone pada Konstruksi Belajar Siswa MTS Negeri 7 Model Jakarta. Al-Izzah: Jurnal Hasil-Hasil Penelitian, 13(2), 241. https://doi.org/10.31332/ai.v13i2.975

Amelia, I., Syamsuri, S., \& Novaliyosi, N. (2020). Identifikasi Proses Penyelesaian Soal Literasi Matematika Siswa Kelas IX Pada Konten Peluang dan Data. Jurnal Cendekia: Jurnal Pendidikan Matematika, 4(1), 331-345. https://doi.org/10.31004/cendekia.v4i2.212

Arikunto dan Jabar. (2010). Evaluasi Program Pendidikan (2nd ed.). Bumi Aksara.

Cecep, C., Mutaqin, A., \& Pamungkas, A. S. (2019). Pengembangan Modul Quick Math Berbasis Mobile Learning sebagai Penunjang Pembelajaran Matematika di SMA. Prisma Sains : Jurnal Pengkajian Ilmu Dan Pembelajaran Matematika Dan IPA IKIP Mataram, 7(2), 100. https://doi.org/10.33394/j-ps.v0i0.1761

Depdiknas. (2003). Undang-Undang Republik Indonesia Nomor 20 Tahun 2003.

Eko Putro Widoyoko. (2012). Teknik Penyusunan Instrumen Penelitian. Pustaka Belajar.

Fany Monica Yuniarti, V., Anriani, N., \& Anwar H. F. Santosa, C. (2020). Pengembangan E-modul Berbasis Smartphone Pada Materi Integral Tak Tentu Berorientasi Keterampilan Abad Ke-21. JARTIKA Jurnal Riset Teknologi Dan Inovasi Pendidikan, 3(2), 222-233. https://doi.org/10.36765/jartika.v3i2.253

Hake, R. R. (1998). Interactive-engagement versus traditional methods: A six-thousand-student survey of mechanics test data for introductory physics courses. American Journal of Physics, 66(1), 64-74. https://doi.org/10.1119/1.18809

Haryanto. (2015). Membangun Kesadaran KritisMelalui Pendidikan. UNY, 1-27. http://staffnew.uny.ac.id/upload/131656343/penelitian/PENDIDIKAN+MENGUBAH+PERAD ABAN.pdf

Hilaliyah, N., Sudiana, R., \& Pamungkas, A. S. (2019). Pengembangan Modul Realistic Mathematics Education Bernilai Budaya Banten untuk Mengembangkan Kemampuan Literasi Matematis 
Siswa. Jurnal Didaktik Matematika, 6(2), 121-135. https://doi.org/10.24815/jdm.v6i2.13359

J.Haq, M. K. (2017). Pengaruh Penggunaan Media Smartphone Sebagai Sumber Belajar Terhadap Motivasi Belajar dan Prestasi Akademik Mata Kuliah Studi Fiqih Mahasiswa Jurusan Pendidikan Agama Islam UIN Maliki Malang. UIN Maliki Malang.

Kemendikbud. (2017). Panduan Praktis Penyusunan E-Modul. 1-57.

Kominfo. (2017). Survey Penggunaan TIK Serta Implikasinya Terhadap Sosial Budaya Masyarakat. Badan Penelitian Dan Pengembangan Sumber Daya Manusia, 1-30.

NCTM. (2020). Principles, Standards, and Expectations. https://www.nctm.org/Standards-andPositions/Principles-and-Standards/Principles,-Standards,-and-Expectations/

Novitasari, \& Wilujeng, H. (2018). Analisis Kemampuan Pemecahan Masalah Matematika Siswa SMP NEGERI 10 TANGERANG. Prima: Jurnal Pendidikan Matematika, 2(2), hal. 137-147.

OECD. (2020). Mathematics performance (PISA). 2018. https://doi.org/OECD (2020), Mathematics performance (PISA) (indicator). doi: 10.1787/04711c74-en (Accessed on 23 February 2020)

Ojose, B. (2011). Mathematics literacy: are we able to put the mathematics we learn into everyday use? Journal of Mathematics Education, 4(1), 89-100.

Pamungkas, R. A. (2020). Pengembangan Media Pembelajaran Menggunakan Kodular Pada Materi Percabangan Dan Perulangan Guna Meningkatkan Pemahaman Siswa. Electronic Theses and Disertation Universitas Muhammadiyah Surakarta. http://eprints.ums.ac.id/81795/

Prastowo, A. (2011). Panduan Kreatif Membuat Bahan Ajar Inovatif. Diva Press.

Pratiwi, I. (2019). Efek Program Pisa Terhadap Kurikulum Di Indonesia. Jurnal Pendidikan Dan Kebudayaan, 4(1), 51. https://doi.org/10.24832/jpnk.v4i1.1157

Putri, D. A., Susanti, V. D., \& Apriandi, D. (2020). Pengembangan Modul Berbasis RME Untuk Meningkatkan Kemampuan Literasi Matematika Siswa Kelas Xi SMK. Prima Magistra: Jurnal Ilmiah Kependidikan, 1(2), 138-146. https://doi.org/10.37478/jpm.v1i2.470

Rahdiyanta, D. (2009). Teknik Penyusunan Modul Pembelajaran. 1-11. http://staff.uny.ac.id/sites/default/files/penelitian/dr-dwi-rahdiyanta-mpd/20-teknik-penyusunanmodul.pdf

Ramadanti, F., Mutaqin, A., \& Hendrayana, A. (2021). Pengembangan E-Modul Matematika Berbasis PBL ( Problem Based Learning ) pada Materi Penyajian Data untuk Siswa SMP. 05(03), 2733-2745.

Solihudin JH, T. (2018). Pengembangan E-Modul Berbasis Web untuk Meningkatkan Pencapaian Kompetensi Pengetahuan Fisika Pada Materi Listrik Statis Dan Dinamis Sma. WaPFi (Wahana Pendidikan Fisika), 3(2), 51. https://doi.org/10.17509/wapfi.v3i2.13731 
Pengembangan E-Modul Berbantu Kodular pada Smarthphone untuk Meningkatkan Kemampuan Literasi Matematis Siswa SMP, Yossy Rizqiyani, Nurul Anriani, Aan Subhan Pamungkas

Wahyuli, I. S. (2017). Pengembangan Modul Berbasis Inkuiri Terbimbing Untuk Memfasilitasi Pemahaman Konsep Matematika Siswa Kelas VIII Sekolah Menengah Pertama Swasta YKPP Sungai Pakning [Universitas Islam Negeri Sultan Syarif Kasim Riau.]. In Repository UIN Suska Riau. https://doi.org/10.18907/jjsre.10.2_212_3 